\title{
The time for pharmaceutical compulsory licensing has expired
}

\author{
Randall Kuhn \& Reed F Beall
}

The compulsory license mechanism is broken and will not bring drug access to the world's
poorest nations. It's time to consider another option-a tax levied on patents-to fund
drugs for developing countries, rather than the erratic compulsory licensing mechanism.
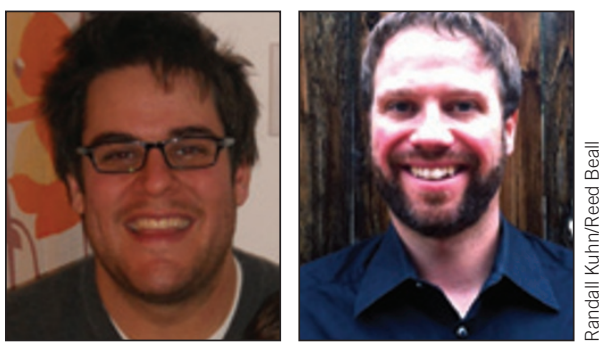

This past spring, China's State Intellectual Property Office sent a concerning message to pharmaceutical companies around the globe when it announced a revision to the country's patent law that would make it easier to issue compulsory licenses, which are governmentissued permits that allow for the targeted production of medicines without the consent of the patent title holder. This move comes 16 years after the World Trade Organization (WTO) in Geneva upheld the right of member states to issue such licenses. But the scale of China's market power clearly has many people paying close attention to the country's next move-all the more because the law allows for drugs made through compulsory licenses to be sold abroad. One can even imagine a day in the future when China might usurp India's leading role in bringing lowcost essential medicines to the world's poorest nations.

Unfortunately, compulsory licenses have historically proven to be an unwieldy tool for promoting pharmaceutical access, especially in poor countries. Our recent evaluation uncovered only 24 episodes since 1995 in which a government official even proposed a compulsory license, with substantially reduced activity since 2008 (PLoS Med. 9, e1001154, 2012). This is in part because patent holders-even though they carry no formal status at the WTO-wield tremendous force by threatening to withdraw their products from the local market or by encouraging their powerful host nations to retaliate against weaker nations.

Pharmaceutical firms are well armed and motivated to fight any potential threat to the existing system. Producers will gladly pay a steep one-time charge to buy off any licensing threats and protect the golden goose. They are helped by the fact that health ministries are generally more interested in receiving price reductions for specific drugs than in dramatically overhauling the patent system. More than half of the episodes in our analysis in which a government official initiated a compulsory licensing process ended with the producer issuing a voluntary license, giving a discount, or simply giving the branded drugs away.

Compulsory licensing activity has been especially rare in low-income countries that were purported beneficiaries of the Doha Declaration, an agreement in 2001 by WTO members. Doha specifically sought to address the fact that many poor nations lack the capacity to produce generic pharmaceuticals by allowing producer nations to export medicines to low-capacity countries under a compulsory license. But we found just one such use of this mechanism. In 2007, Canada exported the HIV/AIDS drug Apo-TriAvir (lamivudine/nevirapine/zidovudine) to Rwanda, a resource- and time-intensive fiasco that did little more than discourage other nations from following suit.

The threat of compulsory licenses did play a part in forcing steep discounts or donations of drugs that treat HIV. For instance, beginning in 2006 Gilead Sciences of Foster City, California, established voluntary licensing and distribution partnerships with Indian generics producers, UNITAID and the Clinton Health Access Initiative to distribute a generic version of tenofovir (brand name Viread) at reduced cost in low-income countries, with a current price of $\$ 159$ per year in 70 such countries compared to about $\$ 7,000$ in rich countries. Notably, the list excluded China. Now that China has made its move, Gilead is reportedly negotiating to donate a substantial amount of tenofovir to China.

Pharmaceutical manufacturers surely must perceive a danger to the patent system that underpins their business model. That's in no small part because China's announcement came hot on the heels of India's decision in March to license Hyderabad-based Natco Pharmaceuticals to produce the cancer treatment Nexavar (sorafenib) over the protests of the patent holder, German drug giant Bayer. Compulsory licenses increasingly target costly cancer treatments in middle-income countries, rather than drugs for communicable diseases in the poorest nations. If countries such as India threaten with more compulsory licenses for drugs that treat noncommunicable diseases, we may see more discounts and donations flow to middle-income countries, possibly at the expense of donations to the poorest nations.

Communicable diseases pose a huge threat to the health of developing nations and cannot be ignored. And although compulsory licensing can act as a failsafe that provides protection in emergencies such as fast-moving epidemics, it is poorly suited to promoting drug access or health equity to address ailments such as malaria and tuberculosis.

Given this reality, we propose an alternative that would more aggressively promote drug access while stabilizing the patent system. With a truly globalized pharmaceutical market size of close to $\$ 1$ trillion, even a relatively small intellectual property tax levied on patents annually on the basis of their value could support novel drug development, purchasing and distribution at a level comparable to all of today's public-private partnerships combined. A progressive rate structure would discourage windfall profit taking. Tax credits or exemptions for drug donations, voluntary licensing and participation in patent pools would provide positive incentives for bringing patented products to the poor without creating conflict. Countries would forgo some of their tax take if they opted out of the system, thus giving them incentives to honor patents.

Although patent-holders would not welcome such a tax, they might pay it in exchange for a drastic reduction in the scope of pharmaceutical compulsory licenses. Patent-holders would gain security for their intellectual property in exchange for making direct financial contributions to the global public good. Nations, particularly poor ones, could tap into a vast pool of new resources for addressing infectious disease burdens and a growing burden of noncommunicable diseases. As so few countries actually benefit from compulsory licenses as they now stand, they may not be missed.

Randall Kuhn is director of the Global Health Affairs Program at the Josef Korbel School of International Studies at the University of Denver,

Denver, Colorado, USA. Reed F. Beall, currently at the University of Denver, will be a PhD student beginning next month at the Population Health Program at the University of Ottawa, Ottawa, Ontario, Canada. 